\title{
Effects of temperature, season and locality on wasting disease in the keystone predatory sea star Pisaster ochraceus
}

\author{
Amanda E. Bates ${ }^{1,2, *}$, Brett J. Hilton ${ }^{1,2}$, Christopher D. G. Harley ${ }^{2}$ \\ ${ }^{1}$ Bamfield Marine Sciences Centre, 100 Pachena Road, Bamfield, British Columbia VOR 1BO, Canada \\ ${ }^{2}$ Department of Zoology, University of British Columbia, 6270 University Boulevard, Vancouver, \\ British Columbia V6T 1Z4, Canada
}

\begin{abstract}
This study investigates wasting disease in the northeast Pacific keystone predatory sea star Pisaster ochraceus on the outer west coast of Vancouver Island (British Columbia, Canada). To quantify the effects of temperature, season and locality on the vulnerability of $P$. ochraceus to wasting disease, we conducted surveys and experiments in early and late summer. To test the prediction that a small increase in temperature would result in heightened infection intensities, we housed sea stars at different temperatures in the laboratory and caged sea stars subtidally at 2 depths. Prevalence and infection intensity were always higher in warm temperature treatments and did not differ between the sexes or with increasing size. Disease effects also varied with season and locality. Specimens held in aquaria displayed significantly higher disease prevalence and infection intensity in June versus August. Furthermore, sea stars from a sheltered inlet showed markedly higher prevalence of the disease in late summer, while wave-exposed sites had consistently low disease prevalence. Seasonal changes in reproductive potential, host condition and/or physiological acclimation, as well as differences in environmental regime among localities, may impact the dynamics of wasting disease. These results demonstrate that small increases in temperature could drive mass mortalities of Pisaster due to wasting disease, with vulnerability possibly reaching a peak in spring and in populations from sheltered localities. This is the most northern report of wasting disease in the class Asteroidea on the west coast of North America.
\end{abstract}

KEY WORDS: Global warming $\cdot$ Temperature $\cdot$ Wasting disease $\cdot$ Pisaster ochraceus $\cdot$ Echinoderm Resale or republication not permitted without written consent of the publisher

\section{INTRODUCTION}

Disease outbreaks are increasing in both frequency and intensity in many marine taxa (Harvell et al. 1999, Ward \& Laffarty 2004, Lester et al. 2007). Global warming is emerging as an important factor driving disease incidence because (1) pathogen growth rates tend to increase at higher temperatures, (2) climate change has enabled pathogen range expansions, and (3) heatstressed hosts are more susceptible to disease (Harvell et al. 2002). As disease incidence increases in populations of ecologically important species, the resultant shifts in the strength of interspecific interactions can have strong impacts on entire communities.
The impacts of disease on echinoderm populations have particularly provided compelling examples of major shifts in ecosystem state and cascading community effects following disease-induced die-offs (reviewed by Uthicke et al. 2009). A classic case occurred in the Caribbean in the 1980s following the widespread pathogen-induced decimation of the herbivorous urchin Diadema antillarum (reviewed by Lessios et al. 1988), when macroalgae overgrew and subsequently replaced corals as the dominant taxa (e.g. Hughes 1994). Thus, disease-mediated local extinctions of marine species, and subsequent community cascades, may be an outcome of global warming. 
One category of disease, referred to as 'wasting disease', has the potential to devastate echinoderm populations because it can rapidly cause death and has been documented in many species that play key community roles (e.g. 10 sea star, 3 sea urchin, 2 brittlestar and 1 sea cucumber species from the northeast Pacific, Eckert et al. 1999; 1 sea star species from the Mediterranean, Staehli et al. 2008). For example, Dungan et al. (1982) attributed mass mortality and large-scale population declines in the sun star Heliaster kubiniji to wasting disease. The etiologic agent responsible for wasting disease is unknown and may vary among species and localities. Attempts to link a bacterium to the disease using molecular tools have not yet been successful (e.g. Staehli et al. 2008); nevertheless, wasting disease progresses in a predictable fashion. Initially, white coloured lesions appear and rapidly grow, followed by loss of turgor, body disintegration, decay, and death (Dungan et al. 1982, Eckert et al. 1999, Staehli et al. 2008). The incidence and progression of wasting disease appear to be highly temperature sensitive. For instance, widespread mortality of several sea stars, including the original keystone species Pisaster ochraceus (hereafter, Pisaster), occurred in association with unusually warm waters during the 1997 El Niño period in the Channel Islands (Eckert et al. 1999). A recent laboratory-based study also documented temperature-dependent mortality from wasting disease in a Mediterranean sea star, Astropecten jonstoni (Staehli et al. 2008).

Our main objective was to investigate variation in disease effects in a keystone species. We quantified the prevalence and infection intensity of wasting disease in Pisaster ochraceus at several localities in Barkley Sound, British Columbia (BC), Canada. We hypothesized that a small increase in temperature would result in a significantly higher spread of the disease and heightened infection intensities. To test this hypothesis, we housed sea stars at different temperatures in the laboratory and in the field. We also conducted experiments to compare the progression of wasting disease in specimens collected in early versus late summer, and from localities that varied in wave exposure. Because Pisaster populations on Vancouver Island are heavily female-biased at larger size classes (Leighton et al. 1991, Stickle \& Kozloff 2008), we also tested for sex or size-biased infection.

\section{MATERIALS AND METHODS}

Study location. Pisaster were collected or surveyed from localities near the Bamfield Marine Sciences Centre (BMSC) (Barkley Sound, BC: $48^{\circ} 50^{\prime} 17^{\prime \prime} \mathrm{N}$, $125^{\circ} 08^{\prime} 26^{\prime \prime} \mathrm{W}$ ) at depths of 0.2 to $1.0 \mathrm{~m}$ (relative to the
Canadian Hydrographic Service chart datum, which approximates the lowest astronomical tide) during low tides in June and August 2008 (Fig. 1). Localities varied in wave exposure, with the 2 Grappler Inlet sites and Bamfield Narrows being protected and the 3 Trevor Channel sites being moderately exposed, as well as in proximity to freshwater inputs (e.g. Sugsaw Creek; Fig. 1).

Infection stage quantification. The aboral surface of sea stars was visually inspected for evidence of lesions, loss of turgor and tissue swelling. Healthy animals were scored as Stage 0. Specimens that displayed signs of the disease were classified into 4 progressive stages (1 to 4 ) based on the criteria outlined in Fig. 2. Mean infection stage was calculated only for infected specimens.

Field surveys. Pisaster ( $\mathrm{n}=100$ per locality) were examined for evidence of wasting disease in June and August at moderately exposed (Ross Islets, Taylor Rock, Scott's Bay) and sheltered (Grappler Mouth and Grappler Narrows) localities (Fig. 1). Sites were selected based on a southwest to west facing aspect and on rock substratum type with slopes from 25 to $45^{\circ}$. We haphazardly selected 100 animals that were $>15 \mathrm{~cm}$ in diameter and were visible within a $100 \times 5 \mathrm{~m}$ belt transect from the water line upwards for surveys. Disease prevalence (percentage of the population with visible signs of wasting disease) and infection intensity (mean infection stage) were calculated.

Experiments. Visibly healthy sea stars were collected for the experiments. In all cases, experimental duration was $96 \mathrm{~h}$.

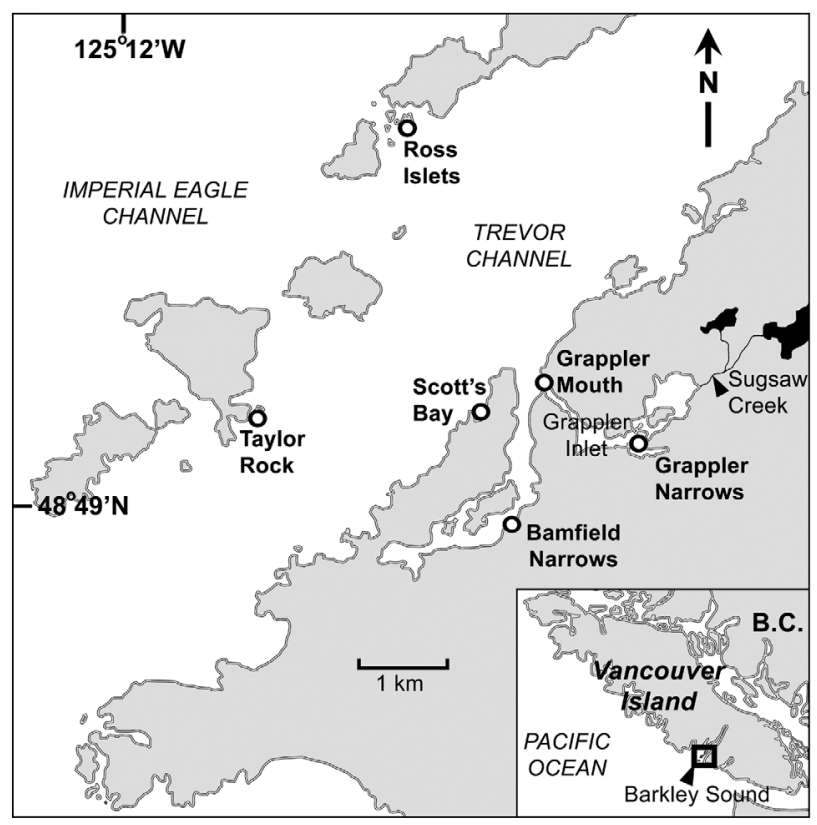

Fig. 1. Rocky shore sampling localities in Barkley Sound on the west coast of Vancouver Island, British Columbia, Canada 

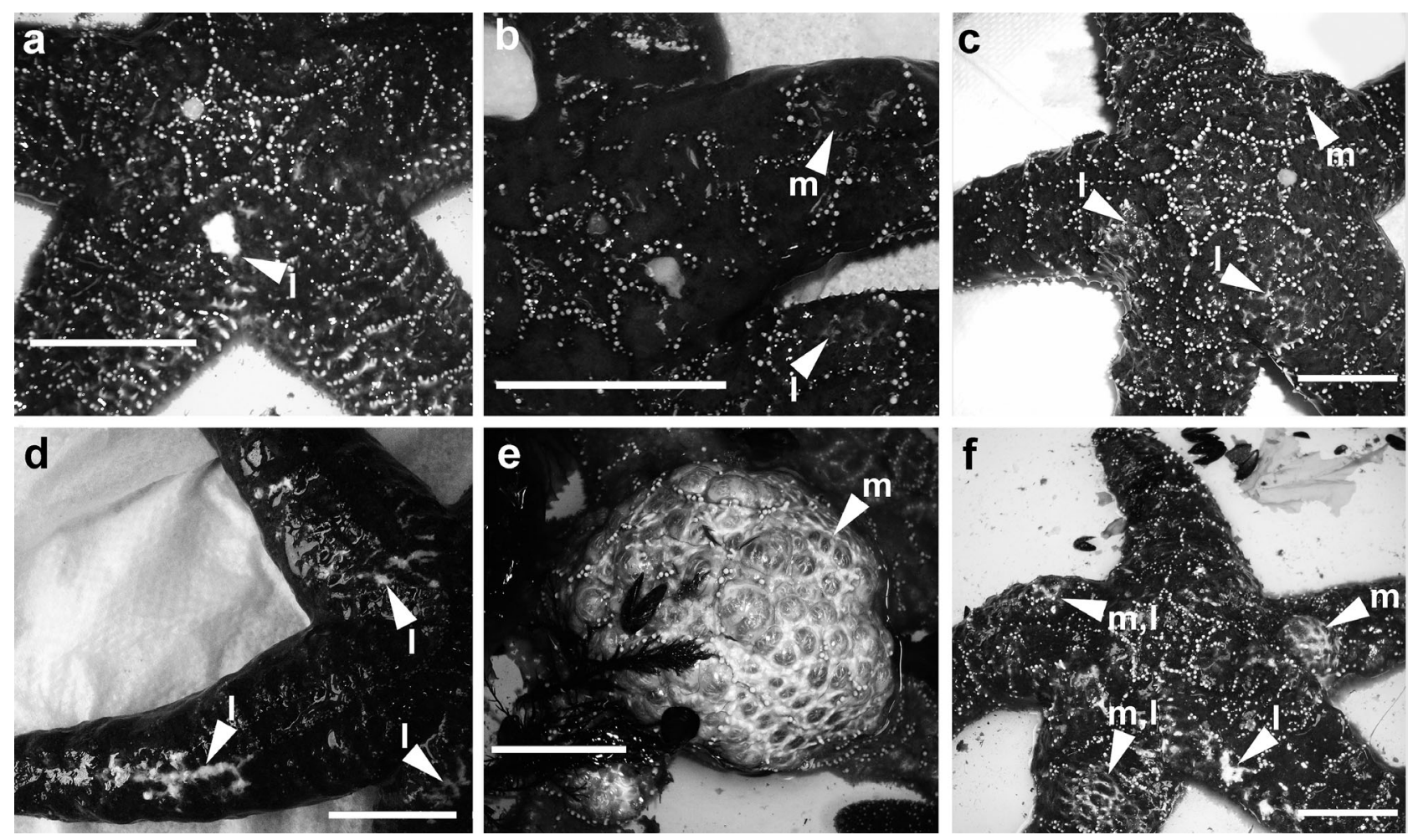

Fig. 2. Pisaster ochraceus. Progressive stages in wasting disease. Stage 1: (a,b) small white lesions (l) are apparent, especially at junctions between the rays; animals display loss of body turgor as evidenced by (b) a distinct mushroom-shaped tissue swelling $(\mathrm{m})$. Stage 2: (c,d) tissue swelling and lesions appear on $>2$ rays. Stage 3: (e) severe tissue swelling and (f) lesions across most of the body surface lead to Stage 4, full body deterioration and death (see also Staehli et al. 2008). Scale bars $=2 \mathrm{~cm}$

Temperature: To quantify the influence of temperature on the prevalence and intensity (mean infection stage) of wasting disease, we conducted laboratory (June) and field (August) experiments. Three replicate laboratory trials were conducted serially from June 10 to 18. In each trial, 70 sea stars (collected from Grappler or Bamfield Narrows; Fig. 1) were divided evenly between 2 flow-through ( $101 \mathrm{~min}^{-1}$ ) sea-tables (250 l seawater). Seawater inflow was directed through a $10 \mathrm{~m}$ length of tygon tubing ( $1 \mathrm{~cm}$ diameter) that was coiled in a seawater bath maintained at 10 or $25^{\circ} \mathrm{C}$ (a $25^{\circ} \mathrm{C}$ water bath achieved a $14^{\circ} \mathrm{C}$ outflow temperature). Two-sample $t$-tests determined the significance level of differences in prevalence of the infection and mean infection stage (calculated for infected specimens only) between the 10 and $14^{\circ} \mathrm{C}$ treatments using trial as the experimental unit ( $n=3$ per temperature), with 35 sea stars per trial.

In the field experiment, Pisaster ( $\mathrm{n}=30$ from Grappler Narrows; Fig. 1) were randomly assigned to one of six $0.4 \mathrm{~m}$ (diameter) $\times 0.2 \mathrm{~m}$ (height) crab traps (mesh size: $\sim 1.5 \mathrm{~cm})$. The cages were divided evenly between 2 depths (1.0 and $9.0 \mathrm{~m}$ ), and hung from a floating dock (BMSC) on August 25. Seawater temperature and salinity were measured daily (14:00 h; YSI conductiv- ity, salinity and temperature meter) at the location of each cage to verify that the abiotic regime differed by depth. Each animal was examined at the completion of the experiment for signs of wasting disease. All Pisaster escaped from 1 cage (9.0 $\mathrm{m}$ depth), thus we pooled data among cages and conducted a 2-sample Monte Carlo randomization test to determine the significance level of differences in scores between the 2 depths using individual sea stars as the experimental unit; uninfected animals (Stage 0) were included with infected animals (Stages 1 to 4 ) in this analysis.

Season: To test for differences in the susceptibility of sea stars to wasting disease following seasonal acclimatization to warmer air and seawater temperatures, we held sea stars at $14^{\circ} \mathrm{C}$ in both June and August. In each month, 20 specimens were collected from Grappler Mouth (Fig. 1) and divided evenly among 4 replicate 201 aquaria (= trials) that were aerated with bubblers (flow rate: $\sim 0.51 \mathrm{~min}^{-1}$ ). In June, aquaria were heated to $14^{\circ} \mathrm{C}$ with electric heaters (100 W Hydor Theo), while ambient seawater temperature was $14^{\circ} \mathrm{C}$ in August. A 2-sample Monte Carlo randomization test determined the significance level of differences in prevalence and mean infection stage between the tem- 
perature treatments, with trial $(\mathrm{n}=4)$ as the experimental unit and 5 sea stars per trial.

Locality: To examine differences in the susceptibility of sea stars between localities, we collected specimens from a sheltered (Grappler Mouth; Fig. 1) and a moderately exposed location (Scott's Bay) on August 30, and compared the prevalence and mean infection stage after $4 \mathrm{~d}$ at $20^{\circ} \mathrm{C}$. The experimental design and statistical analyses are as described above for season.

Sex and size-biased infection: To identify sex or size biases in infection intensity, sea stars included in the June laboratory experiments were sexed and sized (radius). We tested for significant difference in the median infection stage between the sexes with a Mann-Whitney $U$-test; all data from the June laboratory trials were pooled because sex ratio was heavily female-biased ( $70 \%$ female) and the infection stages were not equally represented. A Kruskal-Wallis 1-way ANOVA on ranks tested for size-biased infection intensity among the 4 infection stages.

Statistical analyses. Analyses were conducted in NCSS $2007(\alpha=0.05)$. The various datasets were checked for normality and homogeneity of variances with a kurtosis normality test and a modified Levene equal-variance test; nonparametric equivalents were used when assumptions were not met (as described above for each experiment).

\section{RESULTS}

\section{Field surveys}

Wasting disease was observed in Pisaster populations in June and August 2008 (Table 1). Populations at the 3 localities with moderate wave exposure displayed consistently low disease prevalence $(<1 \%)$, while sea stars in the Grappler Inlet estuary had higher disease preva-

Table 1. Summary of field surveys for wasting disease in Pisaster ochraceus at 5 localities in June and August. Prevalence is no. of sea stars with visible symptoms of wasting disease $\left(n=100\right.$ locality $^{-1}$ and month $\left.^{-1}\right)$. Mean $( \pm 1$ SD) infection stage is calculated for diseased animals only; prevalence therefore equals the sample size for mean infection stage. See Fig. 2 for details of infection stages

\begin{tabular}{|lcccc|}
\hline \multirow{2}{*}{ Locality } & \multicolumn{2}{c}{ Prevalence } & \multicolumn{2}{c|}{ Infection stage } \\
& Jun & Aug & Jun & Aug \\
\hline Taylor Rock & 0 & 0 & 0 & 0 \\
Ross Islets & 0 & 0 & 0 & 0 \\
Scott's Bay & 0 & 1 & 0 & $4^{\text {a }}$ \\
Grappler Mouth & 2 & 36 & $3^{\text {a }}$ & $1.5 \pm 0.5$ \\
Grappler Narrows & 8 & 64 & $1.1 \pm 0.3$ & $1.8 \pm 0.7$ \\
aSample sizes $<3$ & & & & \\
\end{tabular}

lence in both months, albeit markedly so in August (36 and $64 \%$ ). We observed 1 moribund sea star in the field with advanced stages of wasting disease (August, Scott's Bay; Table 1). The majority (>95\%) of diseased sea stars were scored at infection stage 1 or 2 (rays with isolated lesions or patches of tissue swelling).

\section{Experiments \\ Temperature}

Holding sea stars at warmer seawater temperatures $\left(14\right.$ vs. $\left.10^{\circ} \mathrm{C}\right)$ under laboratory conditions resulted in greater proportions of sea stars with wasting disease (1-tailed 2-sample $t$-test: $t=-8.51, \mathrm{p}=0.00052$ ) (Fig. 3a) and higher infection intensity $(t=-7.77, \mathrm{p}=$ 0.0078) after $4 \mathrm{~d}$ (Fig. 3b).
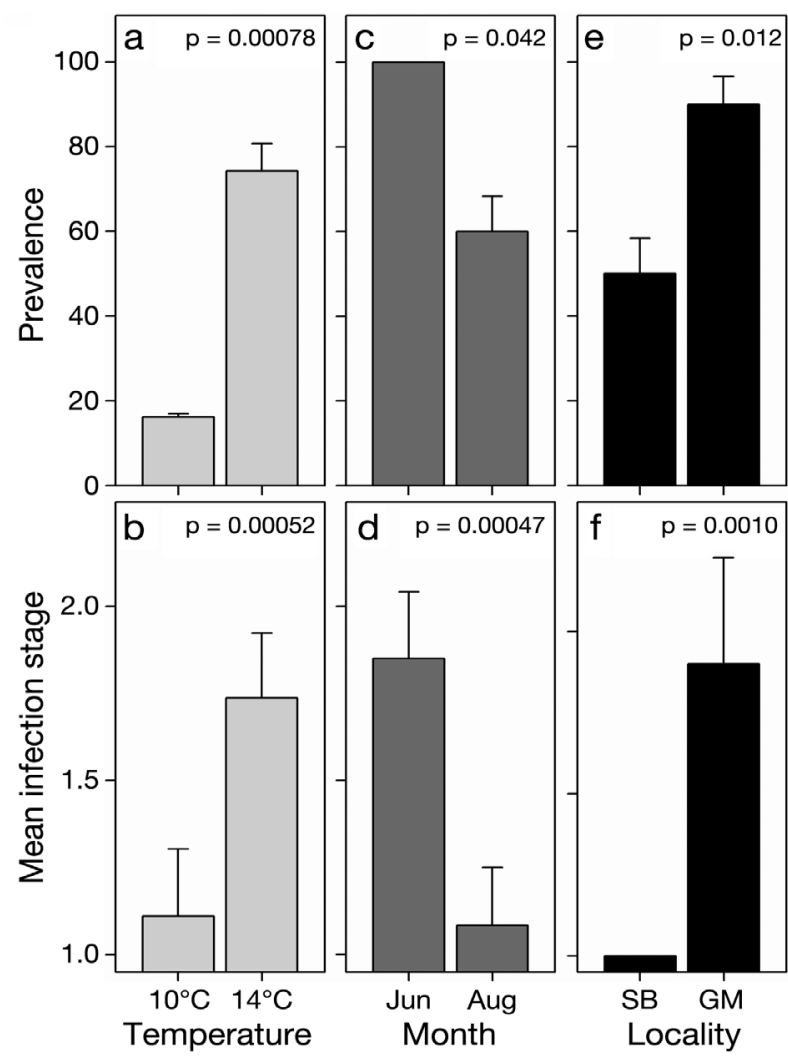

Fig. 3. Pisaster ochraceus. Laboratory experiments testing for differences in mean $( \pm 1 \mathrm{SE})$ prevalence and mean infection stage of infected animals at $(a, b)$ different temperatures, in $(c, d)$ early and late summer, and (e,f) at 2 localities (Scott's Bay: SB; Grappler Mouth: GM). Prevalence and mean infection stage are significantly higher at 14 vs. $10^{\circ} \mathrm{C}$, in early June vs. August, and at Grappler Mouth (sheltered) vs. Scott's Bay (exposed). Means are from $3(\mathrm{a}, \mathrm{b})$ or $4(\mathrm{c}-\mathrm{f})$ trials (see 'Materials and methods' for number of specimens per trial). p-values are reported from 1-tailed 2-sample $t$-tests $(\mathrm{a}, \mathrm{b}, \mathrm{d}, \mathrm{e})$ or Monte Carlo randomization tests $(\mathrm{c}, \mathrm{f})$ 
In the August field experiment, animals were caged at 1 and $9 \mathrm{~m}$ depths. Temperature $(14.8 \pm 0.3$ vs. $11.8 \pm$ $0.2^{\circ} \mathrm{C}$, respectively) and salinity $(29.4 \pm 0.6$ vs. $30.5 \pm$ $0.2)$ were significantly different between the 2 depths (repeated measures MANOVA for effect of temperature: $F=2177.42, \mathrm{p}<0.00001$; effect of salinity: $F=$ $231.03, \mathrm{p}<0.00001)$. Sea stars caged at $9 \mathrm{~m}\left(11.8^{\circ} \mathrm{C}\right)$ remained uninfected, while $60 \%$ of the animals caged at the surface $\left(14.8^{\circ} \mathrm{C}\right)$ displayed early signs of wasting disease (mean infection score of all animals \pm 1SD: $1.1 \pm 0.3$ ) after $4 \mathrm{~d}$. The difference in infection scores between the 2 depths, including uninfected animals, is significant (1-tailed 2-sample Monte Carlo randomization test: $\mathrm{p}=0.0070)$.

\section{Season}

We housed animals from the same location at $14^{\circ} \mathrm{C}$ in 2 different months. In June, we observed significantly higher proportions of Pisaster with visible signs of wasting disease in comparison to specimens collected in late August (1-tailed 2-sample Monte Carlo randomization test: $\mathrm{p}=0.042$ ) (Fig. 3c). Infection intensity was also higher in the June experiment (1-tailed 2-sample $t$-test: $t=6.040, \mathrm{p}=00047$ ) (Fig. 3d).

\section{Locality}

In laboratory experiments conducted in August at $20^{\circ} \mathrm{C}$, Pisaster from a sheltered location displayed significantly higher proportions of animals with wasting disease (1-tailed 2-sample $t$-test: $t=-3.00, \mathrm{p}=0.012$ ) (Fig. 3e) and higher infection intensity (1-tailed 2sample Monte Carlo randomization test: $\mathrm{p}=0.0010)$ in comparison to animals collected from a moderately exposed location (Fig. 3f).

\section{Sex and size-biased infection}

Females and males had similar infection intensities: there was no difference in the median infection stage between the sexes (data were pooled from June experiments: 121 females, 59 males) (Mann Whitney $U$-test: $Z=-1.014, \mathrm{p}=0.31$ ). We also found no difference in the sizes of sea stars classified as healthy (Stage 0) and infected (Stages 1 to 3); Stage 4 was represented by 1 specimen. Infection scores were pooled from warm temperature treatments of the June experiments: $0=27,1=31,2=23$ and $3=9$ ind.) (Kruskal-Wallis 1-way ANOVA on ranks: $\chi^{2}=3.50$, $\mathrm{p}=0.32$ ).

\section{DISCUSSION}

We report wasting disease in Pisaster ochraceus from Barkley Sound, BC, this being the most northern documented case of wasting disease in a member of the class Asteroidea on the west coast of North America. Experiments in the field and in the laboratory indicate that increased temperature during immersion influences the progression and intensity of wasting disease in Pisaster, as has been reported for the Mediterranean sea star Astropecten jonstoni (Staehli et al. 2008). The differences in infection intensity observed between our temperature treatments were quite strong, despite the fact that the experiments only lasted for a few days. Thus, even relatively brief periods of elevated body temperature, as occur during periods of upwelling relaxation (Sanford 1999) and when warm weather coincides with daylight low tides (Helmuth et al. 2002, Harley 2008, Pincebourde et al. 2008), could result in large-scale disease outbreaks. Because Pisaster plays a controlling role in intertidal communities (Paine 1969), disease outbreaks may have far-reaching consequences for intertidal community structure and diversity.

Spatial patterns of wasting disease prevalence may reflect variation in the thermal environment. In August, Pisaster from Grappler Inlet localities displayed higher prevalence (36 to $64 \%$ ) of wasting disease than animals from more exposed locations $(<1 \%)$. Furthermore, experimental animals collected from Grappler Inlet were more vulnerable to infection than animals from Scott's Bay. One explanation for exposure-related variation in disease dynamics is that wave splash at more exposed sites buffers body temperature variation in invertebrates (Harley \& Helmuth 2003) that could result in reduced host susceptibility to temperature-sensitive diseases. Yet there are a number of additional possibilities. For instance, Grappler Inlet receives freshwater input (Sugsaw Creek: Fig. 1) and reduced salinity, factors that may act in concert with temperature to heighten the susceptibility of Pisaster to wasting disease. Dungan et al. (1982) reported a devastating disease outbreak in shallow water populations of the predatory sun star Heliaster kubiniji in 1978 in the Gulf of California during a summer when sea surface temperatures were, on average, $1^{\circ}$ or $2^{\circ} \mathrm{C}$ higher than normal. However, heavy rains in California and the northern Gulf of California during early 1978 also resulted in extremely low salinities on the California coast. In the present study, caged field specimens at 1 versus $9 \mathrm{~m}$ depth experienced slight (29.4 vs. 30.5), but significantly lower, salinities at the surface where sea stars were also more vulnerable to wasting disease. In addition to lower salinity, Grappler Inlet also experiences restricted tidal flushing and sewage inputs, which are factors that can drive high 
bacterial growth yielding disease outbreaks (e.g. in corals; Bruno et al. 2003). The role of these additional factors in contributing to the disease susceptibility of Pisaster remains to be tested.

The prevalence of wasting disease in natural populations peaked in August. However, our experimental data suggest that resistance to the disease was also higher in late summer. Fewer sea stars collected in August versus June (60 vs. $100 \%$ ) developed wasting disease when housed in aquaria. Furthermore, animals displayed more severe symptoms of wasting disease in June. It is possible that selection of healthy individuals for our trials biased our sampling in August towards individuals that were disease resistant. In comparison, June collections would have randomly included more susceptible individuals because wasting disease was at low prevalence. Even so, Pisaster collected from several localities in June (including Scott's Bay where disease prevalence was consistently low) and held at $10^{\circ} \mathrm{C}$ for concurrent experiments on a ciliate association did not survive in aquaria longer than $7 \mathrm{~d}$, due to wasting disease. In contrast, sea stars from both Scott's Bay and Grappler Inlet (collected for this study) were maintained at high densities in seatables at $14^{\circ} \mathrm{C}$ in September for a week after the completion of experiments. During this time, infections did not progress beyond Stage 2, and disease symptoms visibly decreased in most animals that had been exposed to $20^{\circ} \mathrm{C}$. These additional observations support our contention that the vulnerability of Pisaster to wasting disease varies seasonally and may relate to a number of factors such as temporal changes in reproductive condition (Pisaster spawn in spring; Farmanfarmaian et al. 1958), feeding condition (Mauzey 1966), and/or thermal history (Helmuth \& Hoffman 2001).

Subsequent monitoring of Pisaster from Grappler Inlet through September indicated that this population sustained low levels of infection (Stage 1 or 2). The consequences of chronic disease include greater susceptibility to secondary infections (e.g. Kim et al. 2000) and reduced motility (Staehli et al. 2008); such consequences will presumably influence the population and community ecology of rocky shores. Teasing out the various effects of chronic levels of wasting disease on the biology and ecology of Pisaster is an important direction for future research.

Both male and female Pisaster ranging in size from 10 to $20 \mathrm{~cm}$ (radius) were similarly susceptible to wasting disease. Therefore, sex or size-biased mortality from wasting disease can not explain the heavily skewed sex ratios in Vancouver Island populations (e.g. Stickle \& Kozloff 2008). Leighton et al. (1991) proposed that the emerging ciliate parasite Orchitophyra stellarum found infecting the testes of male sea stars drives male-biased mortality. In the present study, we noticed that lesions started at the gonopore in speci- mens with heavy ciliate infestations. Ciliates appeared to consume deteriorated flesh at these lesion sites when observed under a dissecting microscope. It is possible that tissue damage due to feeding by high densities of ciliates may mediate secondary bacterial or fungal infections, and if so, may explain why males might suffer relatively higher mortality than females. Interactions between the ciliate and wasting disease need to be investigated to determine if these 2 diseases drive heightened male mortality in Pisaster.

The agent responsible for wasting disease is elusive, largely because invertebrate surfaces host diverse microbial communities, and linking any one conclusively to the disease is challenging. While bacteria of the genus Vibrio have been implicated in causing mortality of various marine invertebrate groups (e.g. Kushmaro et al. 1998, Nicolas et al. 2002) and were present in bacterial communities isolated from tissues of sea stars with wasting disease (Staehli at al. 2008), we cannot rule out additional causative agents (such as fungi). Identification of the microbe(s) responsible for this disease will be a significant step forward as it will allow interspecific comparisons in pathology and possible environmental detection to determine the various factors that contribute to the incidence, prevalence and intensity of wasting disease in natural populations.

In summary, this study presents evidence that wasting disease in Pisaster is highly temperature sensitive. Infections proceeded to late stages at a faster rate and showed heightened intensities at warmer temperatures in field and laboratory experiments. Three major implications of this work are that (1) Pisaster displays spatial and temporal variation in its susceptibility to wasting disease, (2) populations from sheltered bays appear to sustain chronic, low levels of infection, the ecological consequences of which are unknown, and (3) short-term elevated body temperature (e.g. Pincebourde et al. 2008) due to either warmer air temperatures, sea surface temperatures, or both, could drive mass mortality events of this keystone predator.

Acknowledgements. We thank the staff of the Bamfield Marine Sciences Centre for technical assistance, particularly T. Bird and T. Macdonald. The National Sciences and Engineering Research Council of Canada (NSERC) provided postdoctoral fellowship funding to A.E.B. and a Discovery Grant to C.D.G.H.

\section{LITERATURE CITED}

Bruno JF, Petes LE, Harvell CD, Hettinger A (2003) Nutrient enrichment can increase the severity of coral diseases. Ecol Lett 6:1056-1061

Dungan ML, Miller TE, Thomson DA (1982) Catastrophic decline of a top carnivore in the Gulf of California rocky intertidal zone. Science 216:989-991 
Eckert GL, Engle JM, Kushner DJ (1999) Sea star disease and population declines at the Channel Islands. Proc 5th California Island Symp 5:390-393

Farmanfarmaian A, Giese AC, Boolootian RA, Bennett J (1958) Annual reproductive cycles in four species of west coast starfishes. J Exp Zool 138:355-367

Harley CDG (2008) Tidal dynamics, topographic orientation, and temperature-mediated mass mortalities on rocky shores. Mar Ecol Prog Ser 371:37-46

Harley CDG, Helmuth BST (2003) Local- and regional-scale effects of wave exposure, thermal stress, and absolute vs. effective shore level on patterns of intertidal zonation. Limnol Oceanogr 48:1498-1508

Harvell CD, Kim K, Burkholder JM, Colwell RR and others (1999) Emerging marine diseases - climate links and anthropogenic factors. Science 285:1505-1510

Harvell CD, Mitchell CE, Ward JR, Altizer S, Dobson AP, Ostfeld RS, Samuel MD (2002) Climate warming and disease risks for terrestrial and marine biota. Science 296: 2158-2162

- Helmuth B, Harley CDG, Halpin PM, O'Donnell M, Hofman GE, Blanchette CA (2002) Climate change and latitudinal patterns of intertidal thermal stress. Science 298: 1015-1017

Helmuth BST, Hoffman G (2001) Microhabitats, thermal heterogeneity, and patterns of physiological stress in the rocky intertidal zone. Biol Bull 201:374-384

Hughes TP (1994) Catastrophes, phase shifts, and large-scale degradation of a Caribbean coral reef. Science 265: $1547-1551$

Kim K, Harvell CD, Kim PD, Smith GW, Merkel SM (2000) Fungal disease resistance of Caribbean sea fan corals (Gorgonia spp). Mar Biol 136:259-267

Kushmaro A, Rosenberg E, Fine M, Ben Haim Y, Loya Y (1998) Effect of temperature on bleaching of the coral Oculina patagonica by Vibrio AK-1. Mar Ecol Prog Ser 171:131-137

Editorial responsibility: Mike Hine, Fouras, France
Leighton BJ, Boom JDG, Bouland C, Hartwick EB, Smith MJ (1991) Castration and mortality in Pisaster ochraceus parasitized by Orchitophrya stellarum (Ciliophora). Dis Aquat Org 10:71-73

Lessios HA (1988) Mass mortality of Diadema antillarum in the Caribbean: What have we learned? Annu Rev Ecol Syst 19:371-393

Lester SE, Tobin ED, Behrens MD (2007) Disease dynamics and the potential role of thermal stress in the sea urchin, Strongylocentrotus purpuratus. Can J Fish Aquat Sci 64:314-323

Mauzey KP (1966) Feeding behaviour and reproductive cycles in Pisaster ochraceus. Biol Bull 131:127-144

Nicolas JL, Basuyaux O, Mazurié J, Thébault A (2002) Vibrio carchariae, a pathogen of the abalone Haliotis tuberculata. Dis Aquat Org 50:35-43

Paine RT (1969) A note on trophic complexity and community stability. Am Nat 103:91-93

Pincebourde S, Sanford E, Helmuth B (2008) Body temperature during low tide alters the feeding performance of a top intertidal predator. Limnol Oceanogr 53:1562-1573

Sanford E (1999) Regulation of keystone predation by small changes in ocean temperature. Science 283:2095-2097

Staehli A, Schaerer R, Hoelzle K, Ribi G (2008) Temperature induced disease in the starfish Astropecten jonstoni. JMBA2 Biodiversity Records, available at www.mba.ac. uk/jmba/pdf/5846.pdf

Stickle WB, Kozloff EN (2008) Association and distribution of the ciliate Orchitophrya stellarum with asteriid sea stars on the west coast of North America. Dis Aquat Org 80: $37-43$

Uthicke S, Schaffelke B, Byrne M (2009) A boom and bust phylum? Ecological and evolutionary consequences of density variations in echinoderms. Ecol Monogr 79:3-24

Ward JR, Laffarty KD (2004) The elusive baseline of marine disease: Are diseases in ocean ecosystems increasing? PLoS Biol 2:542-547

Submitted: April 14, 2009; Accepted: August 3, 2009

Proofs received from author(s): October 13, 2009 